\title{
THE EFFECTS OF FORMAL INSTRUCTION ON THE ACQUISITION OF ENGLISH FRICATIVE CONSONANTS OF INDONESIAN EFL LEARNERS
}

\author{
Sukardi Weda, \\ English Literature, \\ Study Program \\ Universitas Negeri Makassar, Indonesia.
}

\author{
Andi Elsa Fadhilah Sakti, \\ English Literature \\ Study Program, Universitas Negeri \\ Makassar, Indonesia
}

\begin{abstract}
Indonesian and English fricative consonants reveal different phonetic classification and symbols in the International Phonetic Alphabet (IPA). English has voiceless labiodental /f), voiceless dental $/ \theta /$, voiceless alveolar /s/, voiceless palato-alveolar (post-alveolar) / $\mathrm{fl}$, voiced labiodental / $/$, voiced dental / //, voiced alveolar / $2 /$, and voiced palato-alveolar (post-alveolar) / $3 /$. Indonesian has voiceless labiodental /f/, voiceless alveolar $/ s /$, voiced labiodental / v/, and voiced alveolar $/ z /$. Indonesian does not have voiceless dental $/ \theta /$, voiced dental $/ \partial /$, voiceless palato-alveolar (postalveolar) /fl, and palato-alveolar (post-alveolar) 13/. The difference in phonetic classification and symbol overlooks subsegmental difference in aspiration that exists between the two. In English there are many sounds symbolized by palato alveolar $/ f /$ and $/ 3 /$, and dental $/ \theta /$ and $/ \partial /$, which are absent in Indonesian. These sounds make difficulties to Indonesian speakers of English. This study therefore aims to find out whether formal instruction improve the acquisition of English fricative consonants by Indonesian learners of English. The population of this study is students of English Literature Study Program Faculty of Languges and Literature Universitas Negeri Makassar Indonesia. The study reveals that formal instruction improved the acquisition of English fricative consonants by Indonesian learners of English.
\end{abstract}

Keywords: Formal instruction, fricative consonants, English, Indonesian learners of English. 


\section{INTRODUCTION:}

(Gimson, 1985a) reveals that each of us uses infinitive number of different speech sounds when we speak English. Gimson therefore argues that it is true to say that it is difficult to produce two sounds which are precisely identical from the point of view of instrumental measurement: two utterances by the same person of the word 'cat' may well show quite marked differences when measured instrumentally.

(Weda, 1998) states that as a foreign language, English presents great difficulties with regard to its pronunciation. The pronunciation of English poses many problems of a different kind from those which we face when we learn our mother tongue (first language). (Gimson A., 1987) points out that, before we try to produce sounds which we are new to us, it is therefore essential that we should perceive the differences between the sounds in the new language, and between the new sounds and those of our own languages with which we have become so familiar. (Weda, 2009) reports from his study that Indonesian university students had difficulties in identifying the stress for 3 to 7 syllable words under the umbrella of phonology. (Weda, 2005) focused on studying stress because Indonesian speakers of English tend to stress words randomly and this phenomenon tends to produce incorrect pronunciation which will give negative effect in maintaing communication with others, especially for the native speakers of English. (Weda, 2014) emphasizes that stress studies under the umbrella of phonology needs serious attention, because there can be unsuitable stress used in communication that may lead to misunderstanding or miscommunication. Weda adds that the accuracy of acceptability of stress in utterances will give a clear signal to the listeners, and improve the quality of speakers' utterances.

The study by (Brown, 2000) sought to experimentaly investigate how the grammars of Japanese speakers, Korean speakers, and Mandarin Chinese speakers affect their acquisition of English contrasts and whether, given the necessary conditions, novel segmental representations can be constructed. Brown found that the acquisition of a second language (L2) is clearly somehow different from that of a first language (L1): adult second language learners rarely (if ever) achieve the same native competence that children do learning their first language and, conversely, children never experience the degree of difficulty that L2 learners do.

Language is unique, because the speaker of language A sometimes meets difficulties in uttering the sounds of Language B but the speaker of language B can produce the sounds of language A easily. This is because, the speaker B is familiar with the sound in his mother tongue, as an example is Indonesian speakers of English can produce $[\mathrm{g}]$ sound at the beginning of a word easily, because this sound can occur at the beginning of Indonesian language, for example at the word ' $y a m b e k$ ' and ' $y i l u$ ' while in English ' $\mathrm{y}$ ' sound is absent at the beginning of a word and the English speaker find difficulties to pronoun the sound in at the beginning of a word. (Fromkin, Rodman, \& Hyams, 2007) gave good example in keeping with this statement. They examplify that a sound such $[\mathrm{n}]$ is difficult for an English speaker to pronounce at the beginning of a word but easy for a Vietnamese speaker means that there is no general notion of "difficulty of articulation" that can explain all of the sound patterns of particular language. For some Buginese speakers in pronouncing plosive /p/, they tend to pronounce labiodental / f/, either in pronouncing Indonesian words, English words, and other languages.

Second language (L2) or Foreign Langauge (FL) leaners sometimes meet difficulties in pronouncing new words in an L2 or FL. In adult language learning, the attempt to master the phonological subtleties of another language can become the source of great difficulty for teacher and student alike when the reality of a learner's target language production does not meet established goals (Reeder, 1997).

The purpose of this study was to determine whether a foreign or second language formal instruction in the pronunciation practice of English fricative consonants causes the pronunciation of those fricative consonants by Indonesian speakers of English as a foreign language (EFL) to become closer to the speakers of English sounds. Two key questions are addressed: Do the students have good pronunciation of English fricative consonants after they followed the pronunciation practice in phonology subject? and what are the constraints of students' pronunciation in English fricative consonants?.

Scovel, in his comprehensive overview of the critical period in 1998, stated that phonological accents in a second language (L2), more than other linguistic skills, would most exhibit age effects because accent was the only part of language that was physical and demanded neuromuscular programming (Ioup, 2008).

Weda (2012) reveals that one of the things that everybody knows about language is that they have different accents. (Roach, 1987) argues that languages are pronounced differently by people from different geographical places, from different social classes, of different ages and different educational background.

\section{LITERATURE REVIEW:}

(Weda, 2012) says that as a second or foreign language in many countries, English presents great difficulties dealing with its language elements (grammar, vocabulary, and pronunciation). The pronunciation of English

International Refereed Research Journal $\mathbf{w}$ ww.researchersworld.com $\mathbf{m}$ Vol.- VIII, Issue - 2(1), April 2017 [15] 
reveals many problems because the way of pronouncing English and Indonesian sounds or phonemes is different. (Karjo, 2016) describes that one of the five phonological factors causing stress placement errors is mispronunciation. Therefore the Indonesian learners of English should understand the sound symbols or phonemes in English. This is because some English consonants differ with Indonesian consonants. Clearly, look at the place and manner of articulation of Indonesian and English as revealed in table 1 and 2.

\section{INDONESIAN CONSONANTS SOUNDS:}

Table 1: Indonesian consonant sounds (Soderberg, 2008)

\begin{tabular}{|l|c|c|c|c|c|c|c|c|}
\hline & Bilabial & $\begin{array}{c}\text { Labio- } \\
\text { dental }\end{array}$ & Dental & Alveolar & $\begin{array}{c}\text { Post- } \\
\text { alveolar }\end{array}$ & Palatal & Velar & Glottal \\
\hline Plosive \& affricate & $\mathrm{p} \mathrm{b}$ & & $\mathrm{t}$ & $\mathrm{d}$ & $\mathrm{t} \mathrm{d}$ & & $\mathrm{kg}$ & $(\mathrm{?})$ \\
\hline Nasal & $\mathrm{M}$ & & & $\mathrm{n}$ & & $\mathrm{n}$ & $\mathrm{j}$ & \\
\hline Flap/trill & & & & $\mathrm{r}$ & & & & \\
\hline Fricative & & (f) & & $\mathrm{s}(\mathrm{z})$ & $(0)$ & & & \\
\hline Approximant & $\mathrm{w}$ & & & & & $\mathrm{j}$ & & \\
\hline Lateral approximant & & & & $\mathrm{l}$ & & & & \\
\hline
\end{tabular}

ENGLISH CONSONANT SOUNDS:

Table 2: Table of English consonant phonemes (Roach, 1987), (Díaz-Campos, 2004)

\begin{tabular}{|l|c|c|c|c|c|c|c|c|}
\hline & Bilabial & Labiodental & Dental & Alveolar & $\begin{array}{c}\text { Palato- } \\
\text { alveolar }\end{array}$ & Palatal & Velar & Glottal \\
\cline { 2 - 9 } & -+ & -+ & -+ & -+ & -+ & & - & + \\
\hline Plosive & $\mathrm{p} \mathrm{b}$ & & & $\mathrm{t} \mathrm{d}$ & & & $\mathrm{kg}$ & \\
\hline Fricative & & $\mathrm{f} \mathrm{v}$ & $\theta \mathrm{d}$ & $\mathrm{s} \mathrm{z}$ & $\int 3$ & & & $\mathrm{~h}$ \\
\hline Affricate & & & & & $\mathrm{f} \mathrm{d} 3$ & & & \\
\hline Nasal & $\mathrm{m}$ & & & $\mathrm{n}$ & & & $\mathrm{l}$ & \\
\hline Lateral & & & & 1 & & & $\mathrm{I}$ & \\
\hline Flap & & & & & $\mathrm{r}$ & & & \\
\hline Approximant & & & & & $1 \mathrm{I}$ & & & \\
\hline Glide & $\mathrm{w}$ & & & & & $\mathrm{j}$ & & \\
\hline
\end{tabular}

\section{THE FRICATIVES OF ENGLISH:}

The fricative consonants in English can be seen in the tabel 3 below:Table 3. The fricative consonants of English (Roach, 1987)

\begin{tabular}{|c|c|c|c|c|c|}
\hline & Labiodental & Dental & Alveolar & Palato-alveolar & glottal \\
\hline $\begin{array}{c}\text { Fortis } \\
\text { (Voiceless) }\end{array}$ & $\mathrm{f}$ & $\theta$ & $\mathrm{s}$ & $\mathrm{f}$ & $\mathrm{h}$ \\
\hline $\begin{array}{c}\text { Lenis } \\
\text { (Voiced) }\end{array}$ & $\mathrm{v}$ & $\jmath$ & $\mathrm{z}$ & 3 & \\
\hline
\end{tabular}

Now we will look at the fricative consonants separately, according to their place of articulation. The following examples are taken from (Roach, 1987) and the figures are taken from (Mannell, 2009).

f, v (example words: 'fan,' 'van'; 'safer,' 'saver;' 'half,' 'halve'). These are labiodental, that is the lower lip is in contact with the upper teeth as shown in Figure 1. The fricative noise is never very strong and is scarcely audible in the case of $v$ (Roach, 1987).

International Refereed Research Journal $\mathbf{n}$ www.researchersworld.com $\mathbf{m}$ Vol.- VIII, Issue - 2(1), April 2017 [16] 


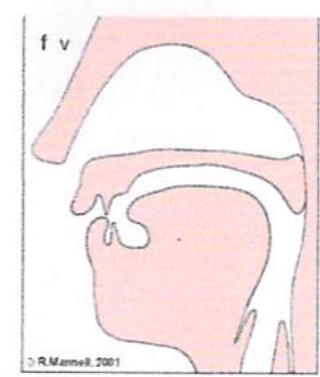

Figure 1: Articulation of Labiodental fricatives (Mannell, 2009)

$\theta$, ð (example words: 'thumb,' 'thus;' 'either,' 'father;' 'breath,' 'beathe'). The dental fricatives have sometimes been described as if the tongue was actually placed between the teeth, and it is common for teachers to make their students do this when they are trying to teah them to make this sound (Road, 1987). In fact, however, the tongue is placed inside the teeth, as shown in Figure 2, with the tip touching the inside of the lower front teeth and the blade touching the inside of the upper teeth. The air escapes through the gaps between the tongue and the teeth (Road, 1987).

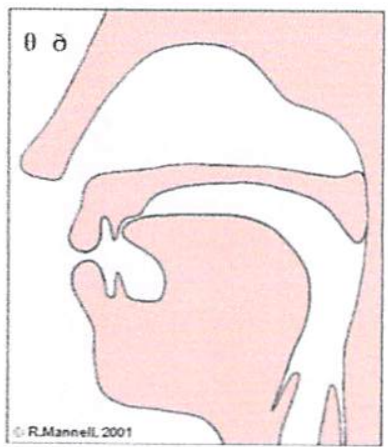

Figure 2: Articulation of dental fricatives (Mannell, 2009)

s, z (example words: 'sip,' 'zip;' 'facing,' 'phasing;' 'rice,' 'rise'). These are alveolar fricatives, with the same place of articulation as $\mathrm{t}$ and $\mathrm{d}$ (Roach, 1987). He adds that to produce alveolar fricatives, the air escapes through a narrow passage along the centre of the tongue, and the sound produced is comparatively intense. The tongue position is shown in Figure 3.

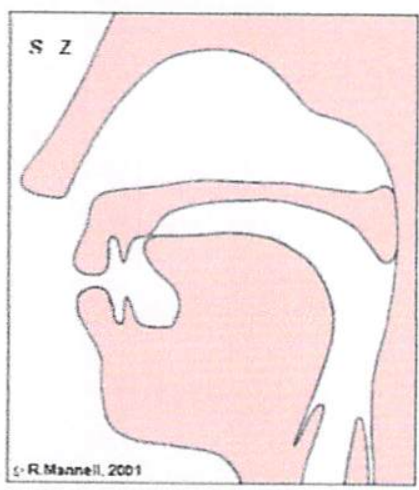

Figure 3: Articulation of alveolar fricatives (Mannell, 2009)

f, 3 (example words: 'ship,' (initial 3 is very rare in English); 'Russia,' ' measure'; 'Irish,' 'garage'). These fricatives are called palato-alveolar, which can be taken to mean that their place of articulation ia partly palatal, partly alveolar (Roach, 1987). He then adds that the tongue is in contact with an area slightly further back than that: for $\mathrm{s}, \mathrm{z}$ as revealed in Figure 4. Roach also suggests that if we make s, then $\int$, we should be able to feel our tongue move backwards in which the air escapes through a passage along the centre of the tongue, as in $\mathrm{s}$ and $\mathrm{z}$, but the passage is a little wider. 


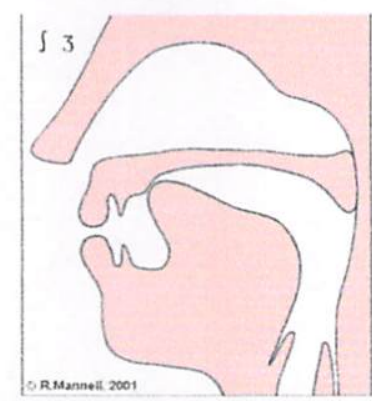

Figure 4: Articulation of palato-alveolar fricatives (Mannell, 2009)

h (example words: 'head,' 'ahead, 'playhouse'). The place of articulation of this consonant is glottal. This means that the narrowing that produces the friction noise is between the vocal cords (Roach, 1987). Roach then adds that if we breathe out silently, then produce $\mathrm{h}$, we are moving our vocal cords from wide apart to close together. Phonologically, $\mathrm{h}$ is a consonant. It is usually found before vowels. As well as being found in initial position it is found medially in words such as: 'ahead' ahed, 'greenhouse' gri:nhaus (Roach, 1987).

\section{PREVIOUS STUDIES:}

In linguistic study domain, phonology is one of the most interesting topics to discuss but very little studies are available about the phonological studies in Indonesian context. May be because, this subject is claimed as one of the most difficult subjects in the area of linguistics. Some students say that phonology is very difficult subject and it needs high concentration to understand each topic revealed in the subject. Some other lecturers avoid to teach phonology because it presents very complicated materials. In keeping with this, (Gimson A. C., 1985a) says that although linguistic science has made rapid and spectacular progress in the present century, it is not merely in modern times that speech and language have been the object of serious study. Extensive study done by Indonesian linguists focusing on the pronunciation and phonology in English in Indonesian context today also becomes difficult effort. Therefore this study focuses on the fricative consonants in English made by Indonesian speakers of English becomes one of endeavors to conduct study in the area of phonology in Indonesia. In the teaching-learning process in the classroom setting, the lecturer should employ a variety of methods and approaches to attract students' involvement and participation. One of the very early methods employed in the classroom is the formal instruction with various activities.

In the international context, some studies have been conducted to show the effects of formal instruction of pronunciation towards the acquisition of pronunciation by L2 or FL learners. (González-Bueno, 1997) demonstrates that afer receiving formal instruction in the pronunciation of Spanish stops, subjects of the experimental group produced Spanish stops with VOT duration at the post test were shorter than the VOT duration of stops produced at the pretest. He adds that formal instruction can account for the improvement in the pronunciation of only these two sounds, $/ \mathrm{p} /$ and $/ \mathrm{g} /$. However, it would appear that the trend towards improvement in the pronunciation of the remaining stops $/ \mathrm{b}, \mathrm{t}, \mathrm{d}, \mathrm{k} /$ by the experimental subjects is also due to formal instruction in the pronunciation of these Spanish sounds. The conclusion of González-Bueno's studies is that the experiment seem to be an indication of some positive effect that formal instruction has on the improvement of the pronunciation of Spanish stops.

(Elliot, 1995) reports that, to determine the success of using formal instruction to improve L2 pronunciation, the research findings revealed that the methodology used for teaching pronunciation can be significantly improved in pronunciation for the subjects in the experimental group. He therefore adds that the type of instruction provided can be described as multimodal consisting of: (a) teaching concrete rules about pont, place, and manner of articulation; (b) designing class presentations on pronunciation that appeal to individual differences in learning styles and preferences-aurally (e.g., listening passages with student attention focused on sound over meaning), orally (e.g., word and sentence repetition exercises), and visually (e.g., the use of articulatory facial diagrams); (c) employing both deductive and inductive modes of teaching pronunciation; (d) providing students with ample drill and practice exercises; and (e) giving immediate feedback in order to prevent phonological fossilization.

(Elliot, 1997) study sought improvement in the L2 pronunciation of the subjects through formal phonological instruction. He states that the subject pronunciation improved significantly for the word reading, sentence repetition, and word repetition exercise. Experimental group pronunciation of the free elicitation portion of the pronunciation test approached statistical significance. (Díaz-Campos, 2004) reveals that other important 
independent variables play a role in L2 pronunciation, specifically, the following eight factor groups were found to be statistically significant; years of formal language instruction, reported use of Spanish before the semester, reported use of Spanish outside the classroom during the semester (days), reported use of Spanish outside the classroom during the semester (hours), gender, entrance OPI, exit OPI, and level at which formal instruction began.

Bui (2016) showed that the EFL learners' problems in pronouncing / $\theta /$ and $/ \delta /$ need attention from the teachers. Along with giving proper instruction, the teachers can acknowledge the students about the possible mistakes they might make. Moreover, it is significant to create an environment in which the students can feel confident and motivated to make use of their English on a regular basis. These studies show the benefits of the inclusion of formal instruction in improving learners' pronunciation in L2 classroom. Similarly, this study examines whether the formal instruction can improve students' pronunciation in fricative consonants.

\section{RESEARCH METHOD:}

Experimental Design and Methodology:

The hypothesis that the present study tests is: Formal instruction in phonology subject improve students' pronunciation in English fricative consonants among Indonesian learners of English. The process of acquisition of fricative sounds of experiment group will improve much more than the pronunciation of a control group which does not receive formal instruction.

In this study, formal instruction is the independent variable and the improvement of the pronunciation of English fricative consonants is dependent variable. The pre-test and post-test of experimental group and control group were analyzed using Statistical Package for Social Sciences (SPSS). In this present study, both the experimental and the control group received identical treatment except for formal instruction as independent variable on English fricative pronunciation, which was given only to the experimental group (English Literature Class A).

Subjects of the Study:

The subjects of the study were 67 students at the English Literature Study Program Faculty of Languages and Literature Universitas Negeri Makassar (UNM), 18 males and 49 females, between 17 and 19 ages. The subjects were registered in the first semester and attended phonology subject.

The experimental group was the class B of the phonology subject and the control group was the class A of the phonology subject.

Table 4: Subjects' Information

\begin{tabular}{|c|c|c|c|c|}
\hline School Level & Major & Semester & N & Gender \\
\hline University & $\begin{array}{c}\text { English Literature } \\
\text { study program }\end{array}$ & $1^{\text {st }}$ Semester & 67 & 18 males, 49 females \\
\hline
\end{tabular}

The subjects were recorded in the beginning of the course. They were asked to read list of words in which they have fricative consonants. After giving formal instruction to experimental group as treatment for 14 meetings, the researcher therefore gave them posttest. The list of words in the posttest was the same in which the researcher asked the subjects to read the words to identify the fricative consonant pronunciation.

Both the experimental and the control groups met for 90 -minutes sessions per week. Only the experimental group received formal instruction in the articulation and perception of English / $f, \theta, s, \delta, v, \delta, z, z /$. The formal instruction consisted of a five to seven minute periods at the beginning of the experimental group. The study was conducted in one semester on September 2016 to January 2017.

In the control class, the instructional pattern was as follows:

1) A theoretical and practical introduction to the articulation of English voiceless and voiced fricative consonants is given. The theoretical introduction explained what fricative consonants consist of, especially in English, with reference to their articulatory, acoustic, and mingographic tracings. Diagrams or picture of articulator position (tongue, teeth, and lips) of organc speech for each fricative consonant which were shown on the slides. For purpose of practice, students were asked to produce the fricative consonants, either in their representation as symbols or as segments in certain words. The teacher frequently gave examples to the students, by producing the fricative consonants followed by the students, the sound symbols pronounced by the lecturer and the students repeated the sounds.

2) Another activity was the students were asked to provide examples of fricative sounds in the words.

3) Finally, the students were asked to present the topics in phonology in group tasks.

International Refereed Research Journal $\mathbf{w}$ www.researchersworld.com $\mathbf{m}$ Vol.- VIII, Issue - 2(1), April 2017 [19] 
The Test:

There are two test in this study. The pre-test was administered at the beginning of the study and the post-test was administered at the last meeting. Between the two tests, there was treatment

given to the students, that is "formal instruction" in which all topics relating to the pronunciation practice and theory of phonology and phonetics, especially the fricative consonant sound. There were a variety of activities in the treatment, those are classroom presentation in which the students presented their slides dealing with the phonological items, consonants, voiced and voiceless consonants, manner of articulation, place of articulation, phonemes, vowels, diphthongs, etc. and the students repeated the sounds after the lecturer.

The words in which the fricative sounds exist can be seen in the following list of words.

Table 5: List of words in fricative consonant testing

\begin{tabular}{|c|c|c|c|c|}
\hline Labiodental /f v/ & Dental / $\theta$ d/ & Alveolar /s $\mathrm{z} /$ & $\begin{array}{c}\text { Palato-aleolar / } \\
3 / \\
\end{array}$ & Glottal /h/ \\
\hline face /feis/ & thing $/ \theta \mathrm{in} /$ & see /si:/ & shoe //u:/ & here /hiə(r)/ \\
\hline laugh /læf/ & health /helo/ & rice /rais/ & action /'æk $/ \mathrm{n} /$ & behind /bi'haind/ \\
\hline very /'veri/ & these /ði:z/ & $\mathrm{zoO} / \mathrm{zu}: /$ & vision/'vizn/ & \\
\hline save /seiv/ & breathe /bri: $\theta$ / & rise /raiz/ & usual /'ju:zl/ & \\
\hline
\end{tabular}

\section{Procedure of Data Collection:}

The data were collected using a written test. The data obtained from the written test were checked to enable the researcher to identify the correct and incorrect pronunciation of English fricative consonants found in the testee in English. The fricative consonant transcription were identified, noted, calculated, and analyzed.

Technique of Data Analysis:

The data will be analyzed using inferential and descriptive statistics (Statistical Package for Social Sciences/SPSS) IBM SPSS Statistics 20 showing the t-test, mean, standard deviation (SD), percentage, and histogram. The most significant source for actual English fricative trancription was Oxford Advanced Learner's Dictionary of Current English by (Hornby, 1987).

\section{RESULTS AND DISCUSSION:}

The performance of the students in the experimental and control groups was shown that the mean score, standard deviation, and percentage of students' correct pronunciation on the fricative English consonants. The means and standard deviation of each fricative consonant and for each group, both at pretest and posttest, were calculated and stated in table 10 and 11.

\section{Pretest (Experimental Group):}

Table 6: Subjects' correct and incorrect transcription percentage in pretest for experimental group

\begin{tabular}{|c|c|c|c|}
\hline $\begin{array}{l}\text { Labiodental } \\
\quad / f \mathrm{v} \text { / }\end{array}$ & Correct & Incorrect & Incorrect Transcription \\
\hline face /feis/ & $32(100)$ & 0 & \\
\hline laugh /læf/ & $\begin{array}{c}10 \\
(31.25)\end{array}$ & $\begin{array}{c}22 \\
68.75) \\
\end{array}$ & $\begin{array}{l}\text { /lev/,/lau/,/lov/,/lauv/,/laugh/,/lav/,/lovr/,/lauegh/,/la:fl/, } \\
\text { /la:ffh/,/leuv/,/laug/ }\end{array}$ \\
\hline very /'veri/ & $\begin{array}{c}31 \\
(96.88)\end{array}$ & $\begin{array}{c}1 \\
(3.12) \\
\end{array}$ & (2) \\
\hline save /seiv/ & $\begin{array}{c}26 \\
(81.25) \\
\end{array}$ & $\begin{array}{c}6 \\
(18.75) \\
\end{array}$ & /seif/,/safe/,/saif/,/sef/,/sef:/ \\
\hline \multicolumn{4}{|r|}{ 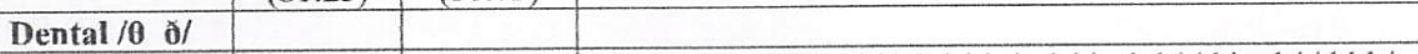 } \\
\hline thing $/ \theta \mathrm{in} /$ & $\begin{array}{c}5 \\
(15.62)\end{array}$ & $\begin{array}{c}27 \\
(84.38) \\
\end{array}$ & $\begin{array}{l}\text { /dzing/,/dzin/,/ting/,/dzink/,/tsin:k/,/ts:ink/,/thingk/,/thi:k/, } \\
\text { /t:ink/,/tink/,/thing/ti:nk/,/tingk/,/ti:nk/,/ti'ng/ }\end{array}$ \\
\hline health /hele/ & $\begin{array}{c}4 \\
(12.5)\end{array}$ & $\begin{array}{c}28 \\
(87.5)\end{array}$ & $\begin{array}{l}\text { /helt/,/helth/,/hel:th/hal:th/,/helt:h/,/hi:lth/,/hel:th/,/hèl:t/ } \\
\text { /hs:It/,/h9:lt/,/hi:elt/,/hi:elt/,/hilth/,/heel/,/ }\end{array}$ \\
\hline these / ði:z) & $\begin{array}{l}2 \\
(6.25)\end{array}$ & $\begin{array}{c}30 \\
(93.75)\end{array}$ & 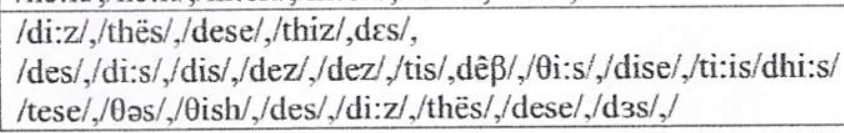 \\
\hline
\end{tabular}

International Refereed Research Journal a www.researchersworld.com a Vol.- VIII, Issue - 2(1), April 2017 [20] 


\begin{tabular}{|c|c|c|c|}
\hline $\begin{array}{l}\text { Labiodental } \\
\quad / f \mathrm{v} /\end{array}$ & Correct & Incorrect & Incorrect Transcription \\
\hline $\begin{array}{l}\text { breathe } \\
\text { /bri: } \partial /\end{array}$ & 0 & $32(100)$ & 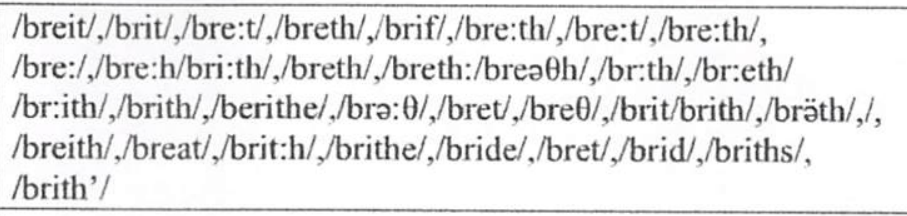 \\
\hline \multicolumn{4}{|l|}{ Alveolar /s z/ } \\
\hline see/si:/ & $32(100)$ & 0 & \\
\hline rice /rais/ & $\begin{array}{c}30 \\
(93.75) \\
\end{array}$ & $\begin{array}{c}2 \\
(6.25) \\
\end{array}$ & /raiz/ \\
\hline zoo /zu:/ & $32(100)$ & 0 & \\
\hline rise /raiz/ & 0 & $32(100)$ & /rais/,/raise/,/r-a-i-s/,/ri:s/,/ris/,/rays/,/ris/,/ \\
\hline \multicolumn{4}{|l|}{$\begin{array}{l}\text { Palato- } \\
\text { aleolar } / \int 3 /\end{array}$} \\
\hline shoe /Ju:/ & $\begin{array}{c}1 \\
(3.12)\end{array}$ & $\begin{array}{c}31 \\
96.88)\end{array}$ & $\begin{array}{l}\text { /syu/,/soe/,/shu/,/s-h-u/,/shü/,/su:e/,/syü/,/sue/,/shu:/,/sow/ } \\
\text { /so/,/su/ }\end{array}$ \\
\hline action /'ækfn/ & $\begin{array}{l}2 \\
(6.25)\end{array}$ & $\begin{array}{c}30 \\
(93.75)\end{array}$ & $\begin{array}{l}\text { /eksyen/,/aktion/,/aktim/,/e-g-s-y-e-n/,/æktion/,/eiktjien/ } \\
\text { /ek:sion/,/3ksion/,/eksen/,/aksyen/,/ekksyen/,/äksyen/, } \\
\text { /ak'sion/,/aksion/,/eksien/,/eksian/,/eksyien/,/eksion/,/ekssyien/, }\end{array}$ \\
\hline vision /'vizn/ & $\begin{array}{c}2 \\
(6.25)\end{array}$ & $\begin{array}{c}30 \\
(93.75)\end{array}$ & $\begin{array}{l}\text { /visyen/,/vison/,/visien/,/v-i-s-y-o-n/,/vision/,/visi:en/,/visiyen/ } \\
\text { /visÿen/,/vision/,/vesion/,/visyion/,/visiyen/,/vision/,/fisi:n/, } \\
\text { /visyien/ }\end{array}$ \\
\hline usual /'ju:zl// & $\begin{array}{c}1 \\
(3.12)\end{array}$ & $\begin{array}{c}31 \\
96.88)\end{array}$ & $\begin{array}{l}\text { /yusual/,/y-u-z-u-a-1/,/uzual/,/uizal/,/ju:zal/,/ususl/ } \\
\text { /yusuel/,/uzuel/,/yuzwel/,/uzual/,/usual/,/u;sual/,/yusuol/, } \\
\text { /yusel/,/'yusual/ }\end{array}$ \\
\hline \multicolumn{4}{|r|}{ 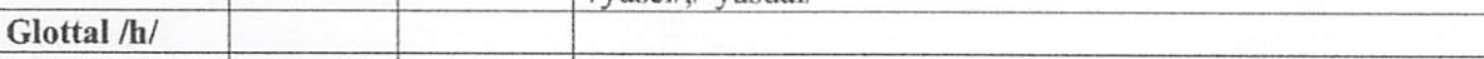 } \\
\hline here /hia(r)/ & $32(100)$ & 0 & \\
\hline $\begin{array}{l}\text { behind } \\
\text { /bi'haind/ }\end{array}$ & $32(100)$ & 0 & \\
\hline
\end{tabular}

\section{Pretest (Control Group):}

Table 7: Subjects' correct and incorrect transcription percentage in pretest for control group

\begin{tabular}{|c|c|c|c|}
\hline Labiodental /f $\mathbf{v}$ / & $\begin{array}{c}\text { Correct } \\
(\%)\end{array}$ & $\begin{array}{l}\text { Incorrent } \\
(\%)\end{array}$ & Incorrect Transcription \\
\hline face /feis/ & $33(94.29)$ & $2(5.71)$ & /ves/ \\
\hline laugh /læf/ & $14(40)$ & $21(60)$ & $\begin{array}{l}\text { /lav/,/logh/,/lou:k/,/,/lagh/,/lau:k/,/lov/,/lakhv/,/lo:uft/, } \\
\text { /legh/,/la:gh/,/laugh/,/laug/,/lau:g/,/lag// }\end{array}$ \\
\hline very /'veri/ & $30(85.71)$ & $5(14.29)$ & /ferui/,/feriy/,/feri/,/'feri/ \\
\hline save/seiv/ & $19(54.29)$ & $16(45.71)$ & /seve/,/sef/,/tsef/,/seif/,/se:f/,/sèif/,/save/,sef/,/saf/,/ \\
\hline \multicolumn{4}{|l|}{ Dental /0 $0 /$} \\
\hline thing / $\theta$ ink/ & $3(8.57)$ & $32(91.49)$ & $\begin{array}{l}\text { /tinkg/,/tink/,/tin:/,/think/,/ting/,/tsink/,/tsing/,/th:ng/, } \\
\text { /thingk/,/thing/,/thin/,/thi:ng/,/ti:ng/,/t:ing/,/sing/,/tingk/ } \\
\text {,/tink/,/:ting/ }\end{array}$ \\
\hline health /hel $\theta$ / & $2(5.71)$ & $33(94.29)$ & $\begin{array}{l}\text { /helt/, } \\
\text { /helth/,/hel:th/,/hal:th/,/helt:h/hèl:t/,/ho:lt,/hi:elt/,/hilth/, } \\
\text { /helt/ }\end{array}$ \\
\hline these /ði:z) & $2(5.71)$ & $33(94.29)$ & $\begin{array}{l}\text { /di:z/,/tese/,/des/,/t-d-i-s-s/,/dis/,/diis/,/dh:es/,/th:s/,/teis/, } \\
\text { /Ois/,/ }\end{array}$ \\
\hline $\begin{array}{l}\text { breathe } \\
\text { /bri: ð/ }\end{array}$ & $1(2.86)$ & $34(97.14)$ & $\begin{array}{l}\text { /breit/, /brit/, /breth/, /brif/, /bre:th/, /bre:t/, /bre:/, /bre:h/, } \\
\text { /bri:th/, /breth:/, /brea } \theta \mathrm{h} / \text {, /br:th/, /br:eth/, /br:ith/, /brith/, } \\
\text { /berithe/, /bra: } \theta /, \text { /bret/, /bre } \theta /, / \text { brith/ }\end{array}$ \\
\hline
\end{tabular}




\begin{tabular}{|c|c|c|c|}
\hline Labiodental /f v/ & $\begin{array}{c}\text { Correct } \\
(\%)\end{array}$ & $\begin{array}{c}\text { Incorrent } \\
(\%)\end{array}$ & Incorrect Transcription \\
\hline \multicolumn{4}{|l|}{ Alveolar /s $\mathbf{z} /$} \\
\hline $\operatorname{see} / \operatorname{si}: /$ & $35(100)$ & 0 & \\
\hline rice /rais/ & $30(85.71)$ & $5(14.29)$ & rai $\beta$ \\
\hline zoo /zu:/ & $34(97.14)$ & $1(2.86)$ & /su:/ \\
\hline rise /raiz/ & 0 & $35(100)$ & /rais/ \\
\hline \multicolumn{4}{|l|}{ Palato-aleolar / 3 / } \\
\hline shoe /Ju:/ & $2(5.71)$ & $33(94.29)$ & $\begin{array}{l}\text { /shu/,/su:/,/syu/,/sue/,/syu:/,/s:yu/,/sho:/,/shu/s/,/shyu/, } \\
\text { /syû/,/shaw/,/sü/,/syu:u/,/su'e/,/shar/,/su/,/sou/,/shu/,/ }\end{array}$ \\
\hline action /'ækfn/ & $2(5.71)$ & $33(94.29)$ & $\begin{array}{l}\text { /eksyen/,/əksyen/,/eksien/,/_ksyien/,/aksyen/,/gksyen/,/ac:ti/ } \\
\text { /action/,/ek:syen/,/æksien/,/ekthem/,/ac:ion/,/aksion/, } \\
\text { /aktion/,/eksio:n/,/aksyion/eksion/ }\end{array}$ \\
\hline vision /'vizn/ & $2(5.71)$ & $33(94.29)$ & $\begin{array}{l}\text { /visien/,/visyen/,,/visi:en/,/vis:o/,/vision/,/fi:syen/,/,/vison/,/ } \\
\text { vition/, } \\
\text { /vissn/,/,/fi:si:en/, } \\
\text { /visin/,/vesyon/,/ }\end{array}$ \\
\hline usual /'ju:zl/ & 0 & $35(100)$ & $\begin{array}{l}\text { /yusual,/yusel/,/uzel/,/yu:sual/,/yusual/,/u:sual/,/juzel/, } \\
\text { /yuzel/,/usel/,/yuzuel/,/yûsual/,/us:1/,/usuel/,/us:1/,/yu:swèl/ } \\
\text { /yu:su:el/,/yuzel/,/usual/,/yuzuəl/,/usual/ }\end{array}$ \\
\hline \multicolumn{4}{|r|}{ (2) } \\
\hline here /hiə(r)/ & $35(100)$ & 0 & \\
\hline behind /bi'haind/ & $35(100)$ & 0 & \\
\hline
\end{tabular}

\section{Posttest (Experimental Group):}

Table 8: Subjects' correct and incorrect transcription percentage in posttest for experimental group

\begin{tabular}{|c|c|c|c|}
\hline Labiodental /f v/ & Correct & Incorrent & Incorrect Transcription \\
\hline face /feis/ & $\begin{array}{c}32 \\
(100)\end{array}$ & 0 & \\
\hline laugh /læf/ & $\begin{array}{c}23 \\
(71.87)\end{array}$ & $\begin{array}{c}9 \\
(28.13)\end{array}$ & /ləv/, /la:v/, /lauv/, /lav/, /lə:v/, /^v/; /lagh/, /1^əf/, /la’v/ \\
\hline very /'veri/ & $\begin{array}{c}32 \\
(100) \\
\end{array}$ & 0 & \\
\hline save /seiv/ & $\begin{array}{c}27 \\
(84.38) \\
\end{array}$ & $\begin{array}{c}5 \\
(15.62) \\
\end{array}$ & /seif/, /se:if/, /sæf/, /sa’f/ \\
\hline \multicolumn{4}{|l|}{ Dental / $\theta$ ठ/ } \\
\hline thing / $\theta$ in/ & $\begin{array}{c}23 \\
(71.87)\end{array}$ & $\begin{array}{c}9 \\
(28.13)\end{array}$ & /ðing/, /din/, /thin/ \\
\hline health /hel $\theta$ / & $\begin{array}{c}17 \\
(53.13)\end{array}$ & $\begin{array}{c}15 \\
(46.87)\end{array}$ & $\begin{array}{l}\text { /helt, /helð/, /holt/, /helth/, /holth/, /head/, /hel:d/he:lt/, } \\
\text { /heælth/, heald/ }\end{array}$ \\
\hline these / ði:z) & $\begin{array}{c}26 \\
(81.25)\end{array}$ & $\begin{array}{c}6 \\
(18.75)\end{array}$ & /di:s/, /dhes/, /te's/, / \\
\hline $\begin{array}{l}\text { breathe } \\
\text { /bri: } ð /\end{array}$ & $\begin{array}{c}21 \\
(65.63)\end{array}$ & $\begin{array}{c}11 \\
(34.37)\end{array}$ & $\begin{array}{l}\text { /bret/, /b:eth/, /bereth/, /bri:th/, /briədh/, /brait:he/, /bri:t/, } \\
\text { /b(r)ith/, /breithe/, /bread/, /breatӨe/ }\end{array}$ \\
\hline \multicolumn{4}{|l|}{ Alveolar /s z/ } \\
\hline see /si:/ & $32(100)$ & 0 & \\
\hline
\end{tabular}

International Refereed Research Journal a www.researchersworld.com m Vol.- VIII, Issue - 2(1), April 2017 [22] 


\begin{tabular}{|c|c|c|c|}
\hline Labiodental /f v/ & Correct & Incorrent & Incorrect Transcription \\
\hline rice /rais/ & $\begin{array}{c}29 \\
(90.63) \\
\end{array}$ & $\begin{array}{c}3 \\
(9.27) \\
\end{array}$ & $/ \mathrm{r} \wedge \mathrm{iz} /, /$ raiz/ \\
\hline $\mathrm{zoo} / \mathrm{zu}: /$ & $32(100)$ & 0 & \\
\hline rise /raiz/ & $\begin{array}{c}17 \\
(53.13) \\
\end{array}$ & $\begin{array}{c}15 \\
(46.87) \\
\end{array}$ & /rais/, /r^is/ \\
\hline \multicolumn{4}{|l|}{ Palato-aleolar / $3 /$} \\
\hline shoe /Ju:/ & $\begin{array}{c}16 \\
(50)\end{array}$ & $\begin{array}{c}16 \\
(50)\end{array}$ & /'syu/,/su:/, /syu:/sui/, /sj:uu/,/shu:/,/syu/, /soe/ \\
\hline action /'æk $\int \mathrm{n} /$ & $\begin{array}{c}16 \\
(50)\end{array}$ & $\begin{array}{l}16 \\
(50)\end{array}$ & $\begin{array}{l}\text { /æksyen/, /\&kzien/, /ek:syen/, /'eksyen/, / }: \text { sion/, /ak:tion/, } \\
\text { /eksen/, æksiæn/. /aksyen/, /ek:syen/, /aksion/, /æctsion/, } \\
\text { /ækan/, /eksion/ }\end{array}$ \\
\hline vision /'vizn/ & $\begin{array}{c}17 \\
(53.13)\end{array}$ & $\begin{array}{c}15 \\
(46.87)\end{array}$ & 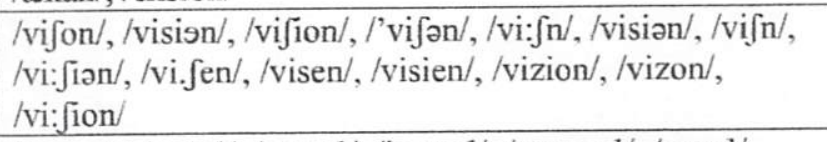 \\
\hline usual /'ju:zl// & $\begin{array}{c}17 \\
(53.13) \\
\end{array}$ & $\begin{array}{c}15 \\
(46.87) \\
\end{array}$ & $\begin{array}{l}\text { /yusual/, /usual/, /yu:sel/, /ju:sual/, /yu.su.al/, /yuzel/, } \\
\text { /usual/, /ju:zuəl/ }\end{array}$ \\
\hline \multicolumn{4}{|l|}{ Glottal /h/ } \\
\hline here /hiə(r)/ & $\begin{array}{c}32 \\
(100)\end{array}$ & 0 & \\
\hline behind /bi'haind/ & $\begin{array}{c}32 \\
(100)\end{array}$ & 0 & \\
\hline
\end{tabular}

\section{Posttest (Control Group):}

Table 9: Subjects' correct and incorrect transcription percentage in posttest for control group

\begin{tabular}{|c|c|c|c|}
\hline Labiodental /f v/ & $\begin{array}{l}\text { Correct } \\
(\%)\end{array}$ & $\begin{array}{l}\text { Incorrent } \\
(\%)\end{array}$ & Incorrect Transcription \\
\hline face /feis/ & $\begin{array}{c}35 \\
(100) \\
\end{array}$ & $x_{1}$ & \\
\hline laugh /læf/ & $\begin{array}{c}29 \\
(82.86) \\
\end{array}$ & $\begin{array}{c}6 \\
(17.14) \\
\end{array}$ & /lı:k/,/lauft/, /lau:c/,/lav/,/laug:h/, /laft/ \\
\hline very /'veri/ & $\begin{array}{c}34 \\
(97.14)\end{array}$ & $\begin{array}{c}1 \\
(2.86)\end{array}$ & l'fe:ri/ \\
\hline save /seiv/ & $\begin{array}{c}24 \\
(68.57)\end{array}$ & $\begin{array}{c}11 \\
(31.43) \\
\end{array}$ & /seif/, /sef/, /sæf/, /səf/, /saf/ \\
\hline \multicolumn{4}{|l|}{ Dental / $\theta$ o/ } \\
\hline thing / $\theta$ ink/ & $\begin{array}{c}17 \\
(48.57)\end{array}$ & $\begin{array}{c}18 \\
(51.43)\end{array}$ & /tin/, /thing/, /ti:ng/, /thin/, /ting/, /tin:k/ \\
\hline health /hel $\theta /$ & $\begin{array}{c}14 \\
(40)\end{array}$ & $\begin{array}{c}21 \\
(60)\end{array}$ & $\begin{array}{l}\text { /'ho,lt/, /helt/, /helt/, /helth/, /he:lf/, /halth/, /'holt/, /halth/, } \\
\text { /həalth/, /hæ:1/, /hælt/, /halth/, /hsalt/, /'hailt/, /hælth/, / }\end{array}$ \\
\hline these /ði:z) & $\begin{array}{c}16 \\
(45.71) \\
\end{array}$ & $\begin{array}{c}19 \\
(54.29)\end{array}$ & $\begin{array}{l}\text { /dis/, /thez/, /di:s/, /the:s/, /thi:z/, /ti:s/, /this/, /these/, /des/, /tis/, } \\
\text { /ei:z/ }\end{array}$ \\
\hline $\begin{array}{l}\text { breathe } \\
\text { /bri: } \text { d/ }\end{array}$ & $\begin{array}{c}12 \\
(34.29)\end{array}$ & $\begin{array}{c}23 \\
(65.71)\end{array}$ & $\begin{array}{l}\text { /briat/, /bred/, /bre:st/,/bræt/,/bria/, /breth/, /bri:th/, /bre;1t/, } \\
\text { /bri:a/, /bre:it/, /brid/, /briath/, /briet:/, /brit/, /brith/, /b:et5/, } \\
\text { /bri:e/ }\end{array}$ \\
\hline \multicolumn{4}{|l|}{ Alveolar /s z/ } \\
\hline see /si:/ & $\begin{array}{c}35 \\
(100) \\
\end{array}$ & 0 & \\
\hline rice /rais/ & $\begin{array}{c}32 \\
(91.43) \\
\end{array}$ & $\begin{array}{c}3 \\
(8.57) \\
\end{array}$ & /raif/, /raic/, /raiz/ \\
\hline zoo /zu:/ & $\begin{array}{c}35 \\
(100)\end{array}$ & 0 & \\
\hline rise /raiz/ & 21 & 14 & /rais/,/ris/, /ra:is/, /rai:s/, /'rais/,/rı:is/,/rıis/ \\
\hline
\end{tabular}

International Refereed Research Journal a www.researchersworld.com a Vol.- VIII, Issue - 2(1), April 2017 [23] 


\begin{tabular}{|c|c|c|c|}
\hline Labiodental /f v/ & $\begin{array}{c}\text { Correct } \\
(\%)\end{array}$ & $\begin{array}{l}\text { Incorrent } \\
(\%)\end{array}$ & Incorrect Transcription \\
\hline & $(60)$ & $(40)$ & \\
\hline \multicolumn{4}{|l|}{ Palato-aleolar / 3 / } \\
\hline shoe /fu:/ & $\begin{array}{c}21 \\
(60)\end{array}$ & $\begin{array}{c}14 \\
(40)\end{array}$ & /shu/, / shoo/, /sou/, /shu:/, /sue/, /su:/, /su/, /syu/, /shu/ \\
\hline action /'æk $\int \mathrm{n} /$ & $\begin{array}{c}16 \\
(45.71)\end{array}$ & $\begin{array}{c}19 \\
(54.29)\end{array}$ & $\begin{array}{l}\text { /æksən/, /eik:sen/, /akshən/, /eksen/, /eksyen/, /’əksyiən/, } \\
\text { /æksən/, /ac:sen/, /aksien/, /əksæn/, /eksion/, /a:syən/, /aksion/, } \\
\text { /'eksyen/, /'æksn/, /astion/, /eksyein/ }\end{array}$ \\
\hline vision /'vizn/ & $\begin{array}{c}18 \\
(51.43)\end{array}$ & $\begin{array}{c}17 \\
(48.57)\end{array}$ & $\begin{array}{l}\text { /vi:sien/, /vitjon/, /vizhan/, /visæn/, /vifn/, /vi:syæn/, /visi:on/, } \\
\text { /vis/, /faasan/, /vijion/, /vзən/, /visien/, /visyien/, /vision/, } \\
\text { /fæsan/, /vifen/, /visien/ }\end{array}$ \\
\hline usual /’ju:zl/ & $\begin{array}{c}15 \\
(42.86) \\
\end{array}$ & $\begin{array}{c}20 \\
(57.14)\end{array}$ & $\begin{array}{l}\text { /yu:sual/, /yə'zual/, /yuzuəl/, /yu:zuel/, /usuəl/, /yuzual/, } \\
\text { /'yuzual/, /usual/, /ju:su:al/, /yu:zuak/, /usuəl/, /yusal/, /usual/ }\end{array}$ \\
\hline \multicolumn{4}{|l|}{ Glottal /h/ } \\
\hline here /hiə(r)/ & $\begin{array}{c}35 \\
(100) \\
\end{array}$ & 0 & \\
\hline behind /bi'haind/ & $\begin{array}{c}35 \\
(100)\end{array}$ & 0 & \\
\hline
\end{tabular}

As revealed in tables 4 and 5 in pretest for experimental and control group, the subjects faced difficulties in pronuncing labiodental fricative ' $\mathrm{f}$ ' in final position for word "laugh" and they met difficulties in pronuncing labiodental fricative 'v' in final posistion for word "save."

In pronuncing dental fricative ' $\theta$ ' and ' $\partial$,' the subjects found difficulties, either in initial position or final position. As illustrated in table 2 and 3, above $90 \%$ of misspronuncing words made by the subjects. The tables 2 and 3 also show that the subject met difficulties in pronuncing palato-aleolar $/ \int$ and $3 /$, in which above $94 \%$ of misspronuncing words made by the subject, either in initial or final position. The subjects also met difficulties in pronuncing alveolar ' $z$ ' in final position, as in word "rise," and $100 \%$ of misspronuncing words made by the subjects, either in pretest or in posttest. In posttest for experimental and control group as shown in table 6 and 7 , in posttest for control group, the subjects still met difficulties in pronuncing dental ' $\theta$ ' in initial and final position, where there were above $50 \%$ of misspronuncing words made by the subjects, either in initial and final position. They also met difficudlties in pronuncing dental ' $\varnothing$ ' in initial and final position, where there were above $50 \%$ of the subjects misspronunciang in words "thing," "health," "these," and "breathe."

In posttest for experimental group, the misspronuncing words were under $50 \%$. This means that there were some great changes made by the subjects after giving formal instruction in the classroom setting.

Therefore, the statistical testing reveals that the formal instruction improved the subjects' acquisition of fricative consonants as illustrated in the following mean score, standar deviation (SD), significance test, and t-test.

This present study was designed to determine the success of using formal instruction to improve EFL pronunciation. The findings revealed that the methodology used for teaching pronunciation significantly improved the pronunciation for the subjects in the experimental group. The type of formal instruction consisting of: (i) speech organs, (ii) teaching concrete rules about point and manner of articulation, (iii) consonants, (iv) chart of cardinal vowels, (v) short and long vowels, (vi) diphthongs, (vii) triphthongs, (viii) stress. After attending mid-term test, the subjects were grouped into 6 and they presented their group tasks on different topics to practice their pronunciation and understanding.

Test of significance (t-test) was used to test the hypothesis. This test was used to identify the significant difference between the results of students' mean score of the students who were taught the subject using formal instruction and the students who were taught the subject using conventional way. In conventional way, the teacher focused on transferring materials or topics in front of the classroom without classroom presentation of the students.

Table 10: The mean score and standard deviation of students' pretest

\begin{tabular}{|l|c|c|c|}
\hline \multicolumn{1}{|c|}{ Group } & Sample & Mean Score & Standard Deviation \\
\hline Experimental & 32 & 8.16 & 2.23 \\
Control & 35 & 7.80 & 2.15 \\
\hline
\end{tabular}

International Refereed Research Journal w www.researchersworld.com n Vol.- VIII, Issue - 2(1), April 2017 [24] 
Tabel 10 reveals that the mean score of experimental group in pretest was 8.16 with standard deviation was 2.23 and the mean score of control group in pretest was 7.80 with standard deviation was 2.15 . This means that both experimental and control group categorized in fair classification.

Table 11. The mean score and standard deviation of students' posttest

\begin{tabular}{|l|c|c|c|}
\hline Group & Sample & Mean Score & Standard Deviation \\
\hline Experimental & 32 & 13.50 & 0.51 \\
Control & 35 & 12.66 & 0.61 \\
\hline
\end{tabular}

Tabel 11 shows that the mean score of experimental group in posttest was 13.50 with standard deviation was 0.51 and the mean score of control group in posttest was 12.66 with standard deviation was 0.61 . This means that both experimental and control group in posttest was categorized in good classification.

Table 12: The difference of mean score between pretest of experimental and control group

\begin{tabular}{|c|c|c|c|c|}
\hline \multirow{2}{*}{$\begin{array}{c}\text { Consonant } \\
\text { Acquisition }\end{array}$} & \multicolumn{2}{|c|}{ Mean Score } & \multirow{2}{*}{ Difference } & \multirow{2}{*}{ P. Value } \\
\cline { 2 - 3 } $\begin{array}{c}\text { Fricative } \\
\text { Consonants }\end{array}$ & 8.16 & 7.80 & 0.36 & 0.000 \\
\hline
\end{tabular}

Table 12 illustrates that the probability value was 0.000 is smaller than 0.05 at the level of significance $(0.000<0.05)$. This means that there is a significant difference between control group and experimental group. This reveals that the acquisition of English fricative consonants of the students of experimental group is significantly higher than the control group.

Table 13: The difference of mean score between posttest of experimental and control group

\begin{tabular}{|c|c|c|c|c|}
\hline \multirow{2}{*}{$\begin{array}{c}\text { Consonant } \\
\text { Acquisition }\end{array}$} & \multicolumn{2}{|c|}{ Mean Score } & \multirow{2}{*}{ Difference } & \multirow{2}{*}{ P. Value } \\
\cline { 2 - 3 } $\begin{array}{c}\text { Fricative } \\
\text { Consonants }\end{array}$ & 13.50 & 12.66 & 0.84 & 0.000 \\
\hline
\end{tabular}

Figure 5 plots mean acquisition of fricative consonants in experimental group. The figure shows a positive improvement of students' pronunciation on the fricative consonants after treatment whereby $\mathrm{p}<.05$ and the improvement is strong. Therefore, figure 6 plots mean acquisition of fricative consonants in control group. The figure reveals a positive improvement whereby $\mathrm{p}<.05$, but the changes in experimental group was bigger than in control group.

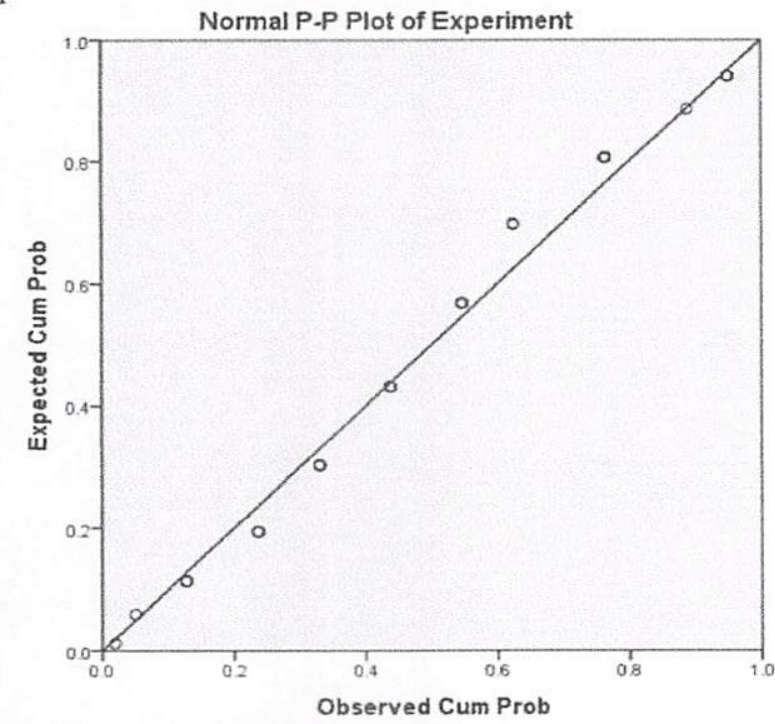

Figure 5: Plots of experimental group in posttest

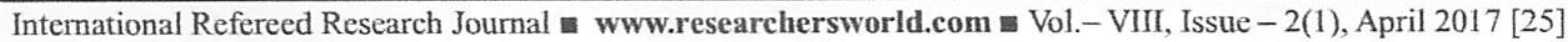




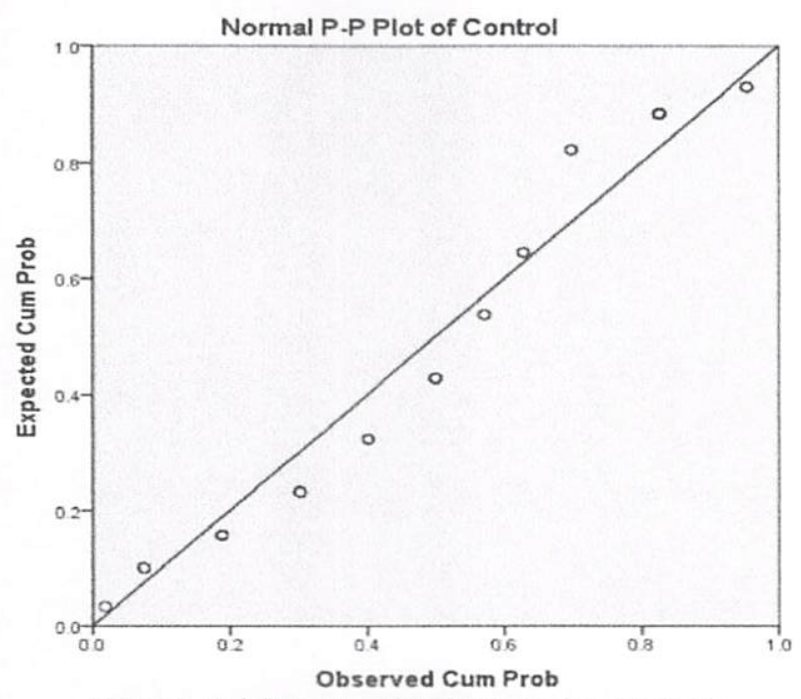

Figure 6: Plot of control group in posttest

Table 13 shows that the probability value was 0.000 is smaller than 0.05 at the level of significance $(0.000<0.05)$. This means that there is a significant difference between control group and experimental group in posttest. This reveals that the acquisition of English fricative consonants of the students of experimental group is significantly higher than the control group after treatment.

From the inferential statistics, we can see that there was significant improvement of students' fricative consonant acquisition after giving formal instruction in the classroom setting. The mean scores of the pretest and posttest of both experimental and control group are shown in chart 1 below.

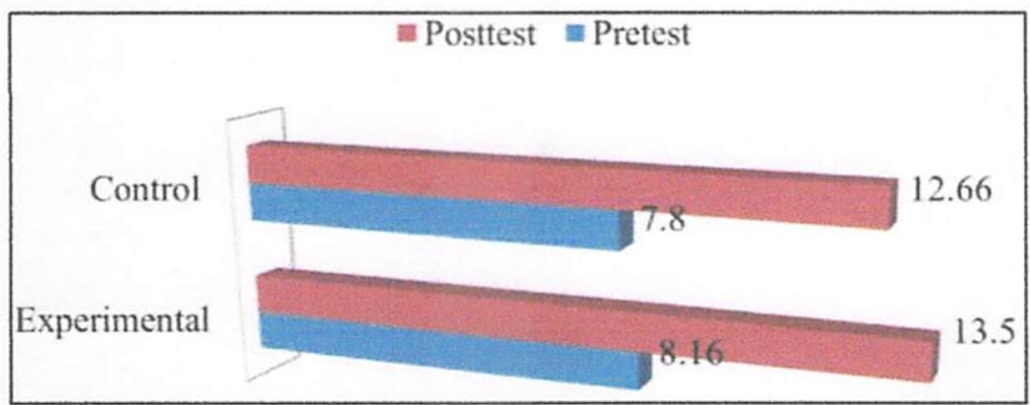

Chart 1: The mean score of both pretest and postest in experimental and control group

Chart 1 shows the means score of control group and experimental group in pretest and posttest. The mean score of experimental group in pretest was 8.16 and the mean score of control group in pretest was 7.80 . In posttest, the mean score of experimental group was 13.50 and the mean score of control group was 12.66.

\section{CONCLUSION:}

Based on the two key questions as previously stated. The study therefore concludes that the students have pronunciation improvement of English fricative consonants after they followed the phonology subject using formal instruction.

The constraints of students' pronunciation in English fricative consonants were that the students felt difficulties in pronuncing labiodental fricative ' $\mathrm{f}$ ' in final position for word "laugh" and they met difficulties in pronuncing labiodental fricative ' $v$ ' in final posistion for word “save." In pronuncing dental fricative ' $\theta$ ' and ' $\partial$,' the subjects found difficulties, either in initial position or final position. As revealed in the discussion, above $90 \%$ of misspronuncing words made by the subjects. In pronuncing palato-aleolar $/ \int$ and $3 /$, there were above $94 \%$ of misspronuncing words made by the subject, either in initial or final position. The subjects also met difficulties in pronuncing alveolar ' $z$ ' in final position, as in word "rise," and $100 \%$ of misspronuncing words made by the subjects, either in pretest or in posttest.

Therefore, in posttest for experimental and control group, the subjects still met difficulties in pronuncing dental

$\overline{\text { International Refereed Research Journal a www.researchersworld.com a Vol.- VIII, Issue - 2(1), April 2017 [26] }}$ 
' $\theta$ ' in initial and final position, where there were above $50 \%$ of misspronuncing words made by the subjects, either in initial and final position. They also met difficudlties in pronuncing dental ' $\gamma$ ' in initial and final position, where there were above $50 \%$ of the subjects misspronunciang in words "thing," "health," "these," and "breathe."

\section{REFERENCES:}

Brown, C. (2000). The interrelation between speech perception and phonological acquisition from infant to adult. In J. (. Archibald, Second language acquisition and linguistic theory (pp. 4-63).

Díaz-Campos, M. (2004). Context of learning in the acquisition of Spanish second language phonology. SSLA, $26,249-273$.

Elliot, A. R. (1995). Foreign language phonology: Field independence, attitude, and the success of formal instruction in Spanish pronunciation. The Modern Language Journal, IV, 79.

Elliot, A. R. (1997). On the teaching and acquisition of pronunciation within a communicative approach. Hispania, 80(1), 95-108.

Fromkin, V., Rodman, R., \& Hyams, N. (2007). An Introduction to Language. Boston: Thomson Wadsworth.

Gimson, A. (1987). A practical course of English pronunciation. Hongkong: Wing King Tong Co. Ltd.

Gimson, A. C. (1985a). An Introduction to the Pronunciation of English. London: Edward Arnold.

González-Bueno, M. (1997). The effects of formal instruction on the acquisition of Spanish stop consonants. Contemporary perspectives on the acquisition of Spanish. In W. R.-L. Glass, Production, processing, and comprehension (Vol. 2).

Hornby, A. (1987). Oxford Advanced Learner's Dictionary of Current English. Oxford: Oxford University Press.

Ioup, G. (2008). Exploring the role of age in the acquisition of a second language phonology. In J. G. Erwards, Phonology and Second Language Acquisition. Amsterdam: John Benjamins Publishing Co.

Karjo, C. (2016). Accounting for L2 learners' errors in word stress placement. In Indonesian Journal of Applied Linguistics, 5(2), 199-208.

Mannell, R. (2009). Phonetics and phonology: Articulation of fricatives. Sydney: Macquarie University. Retrieved November 17, 2016, from http://clas.mq.edu.au/speech/phonetics/phonetics/consonants/fricatives.html

Reeder, J. T. (1997). Mimephonic ability and phonological performance in adult learners of Spanish. Contemporary perspectives on the acquisition of Spanish. In W. R.-L. Glass, Production, processing, and comprehension. Somerville: Cascadilla Press.

Roach, P. (1987). English phonetics and phonology: A practical course. Cambridge: Cambridge University Press.

Soderberg, C. D. (2008). Indonesian. Journal of the International Phonetic Association, 38(2), 209-2013. Retrieved November $\quad 17, \quad 2016$, from https:/www.cambridge.org/core/services/aop-cambridgecore/content/view/AE405481B94A4E0B7234A8BBE9C6F5FD/S0025100308003320a.pdf/indonesian.pdf

Weda, S. (1998). Interlanguage phonology: stress shifts of English utterances made by Indonesian speakers of English. In U. thesis. Makassar: Graduate Program Hasanuddin University.

Weda, S. (2005). Interlanguage phonology: stress shifts of English utterances made by Indonesian speakers of English. In Conference on English Studies (Conest): 2 Proceedings. Jakarta: Pusat Kajian Bahasa dan Budaya Universitas Katolik Atma Jaya.

Weda, S. (2009). Interlanguage phonology: stress shifts of English utterances made by Indonesian university students. In Proceedings, Kongres Internasional Masyarakat Linguistik Indonesia (KIMLI) 2009. Batu: Kerjasama MLI dengan Direktorat Jenderal Pendidikan Tingi Kementerian Negara Koordinator Kesejahteraan Rakyat, dan Universitas Negeri Malang.

Weda, S. (2012). Stress shifts of English utterances made by Indonesian speakers of English (ISE). International Journal of English Linguistics, 2(4), 23-32.

Weda, S. (2014). Interlanguage phonology: stress shifts of English utterances made by Indonesian university students. English and Literature Joumal, 1(3), 1-17. 